\title{
The Carotene Content of Green and Ripe Plantains ${ }^{1}$
}

\author{
Conrado F. Asenjo and Elba I. Porrata ${ }^{2}$
}

\section{INTRODUCTION}

Plantain (Musa paradisiaca L.), either in the green or ripe stage, is extensively used in the Puerto Rican dietary although it must be cooked to be edible. In the survey of approximately 1,000 Puerto Rican families conducted by Robert and Steffani (1), ${ }^{3}$ they found that 61.5 percent often used green, and 48.6 percent often used ripe plantains. It is also interesting to point out that the green plantain headed the list among the starchy vegetables in the order of preference, while the ripe plantain occupied the fourth place.

\section{LITERATURE REVIEW}

The information found in the literature on the carotene and vitamin A content of green and yellow plantains is very fragmentary. The only specific investigation on the subject found by us was that by Gómez and Mattill (2). They studied the carotene content of plantains during the progress of color change from stage 1 to stage 8 . They found that, irrespective of the color stage, the carotene content fluctuated within the narrow limits of 2.4 to $3.9 \mu \mathrm{g}$. per gram of raw edible material. They did not determine carotene by the chromatographic method, but by a special extraction procedure.

All the other data on the carotene or vitamin A content of plantain have been of a fragmentary nature. Quinn and Cook (3) reported that plantains (state of maturity not indicated) purchased in Spanish stores in New York City contained 10 Sherman units of vitamin A per gram of the edible portion. Axtmayer and Cook (4) found that green Puerto Rican plantains, after being boiled in water, contained 20 Sherman units of vitamin A per gram of the edible portion. Munsell, et al. (5) (6) (7) (8) (9) (10), reported the results of analysis in 21 samples from Central America. The average carotene content was $3.6 \mu \mathrm{g}$. per gram. Their values ranged from 0.1 to 8.3 $\mu \mathrm{g}$. per gram. Only one sample was green and it was $2.1 \mu \mathrm{g}$. lower than the average. Five samples of plantains from Mexico, of no stated stage of maturity, were reported by Cravioto, et al. (11), to contain between 2.5 and 9.0, and to average $5.0 \mu \mathrm{g}$. of carotene per gram of the edible portion.

${ }^{1}$ A cooperative project with the Agricultural Experiment Station, University of Puerto Rico, Rio Piedras, P. R.

2 Department of Biochemistry and Nutrition, School of Medicine, School of Tropical Medicine, University of Puerto Rico, San Juan 22, P. R.

${ }^{3}$ Numbers in parentheses refer to Literature Cited pp. 155-6. 
Navia, et al. (12), in 6 samples of plantains from Cuba, reported values ranging from 0.6 to 20.0 , and averaging $6.6 \mu \mathrm{g}$. per gram of the edible portion. They pointed out that a green "plátano macho" had a significantly higher carotene value than the rest.

\section{OBJECTIVE}

It was the purpose of this investigation to determine the content of carotene in green and ripe Puerto Rican plantains as sold to the consumer in different markets in the San Juan metropolitan area.

\section{MATERIALS AND METHODS}

Thirty-three different samples of totally green or ripe plantains, bought in different markets throughout the San Juan metropolitan area, were assayed for carotene using the standard chromatographic procedure recommended by the Association of Vitamin Chemists (13). Briefly it is as follows:

A representative sample of plantain containing about $250 \mu \mathrm{g}$. of carotene was weighed out. It was cut into small pieces and blended with acetone in a mechanical blendor. The acetone extract was transferred and the solid slurry remaining behind was mixed with a small quantity of water and blended again with petroleum ether until no color was extracted. The acetone extract, after adding some water, was also extracted with petroleum ether until no color was removed. All petroleum ether extracts were combined, dried over anhydrous $\mathrm{Na}_{2} \mathrm{SO}_{4}$, filtered, and concentrated to a volume of about $15 \mathrm{ml}$.

This concentrate was chromatographed in a column 2 to $2.5 \mathrm{~cm}$. in length composed of a mixture of $1: 1$ of $\mathrm{MgO}$ and Super-Cel. The petroleum ether extract was poured into the column and suction was applied. After the chromatogram was developed it was eluated with a mixture of 3-percent acetone in petroleum ether until the desired pigments had moved off the column and the filtrate was colorless. The contents of the filtering flask were transferred to a volumetric flask and diluted by adding eluant to volume. The intensity of color was determined at $450 \mu$ in a spectrophotometer. The calibration curve was prepared using carotene (B 90 percent, $\alpha 10$ percent) diluted in eluant mixture. Concentrations ranging from 0.2 to $2.4 \mu \mathrm{g}$. per milliliter were used.

The results were expressed as micrograms ( $\mu \mathrm{g}$.) of carotene per gram of edible portion.

In order to use a different approach than the chemical assay, 28 day-oldwhite rats (Wistar-STM strain) were placed on the U. S. Pharmacopoeia (14) vitamin A-free diet. In a period of 4 to 5 weeks they showed signs of vitamin A deficiency such as cessation of growth and slight xerophthalmia. 
Fourteen rats received a daily supplement of $0.2 \mathrm{mg}$. of the standard U.S.P. vitamin A acetate solution in oil, equivalent to 2 I.U. of vitamin A per day. Sixteen animals received as supplement $0.2 \mathrm{gm}$. of green plantain, and an equal number the same quantity of ripe plantain per day. An additional group of $\mathbf{1 6}$ animals were left as negative controls, receiving no supplement.

\section{RESULTS}

The average carotene content of the green plantain was found to be $10.43 \mu \mathrm{g}$. per gram of edible portion, while the ripe plantain contained only

TABLE 1.-Carotene content of green and ripe plantains as determined by the chromatographic method

\begin{tabular}{|c|c|c|c|c|c|}
\hline Condition of plantain & Samples & $\begin{array}{l}\text { Content of } \\
\text { carotene as } \\
\text { B carotene }\end{array}$ & $\begin{array}{l}\text { Standard } \\
\text { deviation }\end{array}$ & $\sigma$ diff. & t \\
\hline $\begin{array}{l}\text { Green } . \ldots \ldots \ldots \ldots \ldots \\
\text { Ripe............ }\end{array}$ & $\begin{array}{c}\text { Number } \\
33 \\
33\end{array}$ & $\begin{array}{c}\mu g . \text { per gram } \\
10.46 \\
6.68\end{array}$ & $\begin{array}{l}3.66 \\
2.97\end{array}$ & 0.82 & 4.5 \\
\hline
\end{tabular}

TABLE 2.-Rat-growth assay of green and ripe plantains

\begin{tabular}{c|c|c|c|c}
\hline \multicolumn{1}{c|}{ Supplement fed } & Animals & $\begin{array}{c}\text { Supplement } \\
\text { per day }\end{array}$ & $\begin{array}{c}\text { Rats that died } \\
\text { during the } \\
\text { experimental } \\
\text { period }\end{array}$ & $\begin{array}{c}\text { Average gain or } \\
\text { loss weight in 4 } \\
\text { weeks }\end{array}$ \\
\hline U.S.P. standard vitamin A & & Grams & Number & Grams \\
acetate.................... & 14 & $0.002^{1}$ & 2 & \\
Green plantain............... & 16 & .2 & 2 & 28 \\
Ripe plantain............... & 16 & .2 & 4 & 11 \\
Negative controls............ & 16 & 2 & 12 & -31 \\
\hline
\end{tabular}

1 Equivalent to 2 I.U. vitamin A per day.

2 None.

$6.68 \mu \mathrm{g}$. per gram. The difference between the two groups is highly significant, the value of $t$ being 4.5, as shown in table 1 .

Rat assay for provitamin A activity indicated that the green plantain protected the rats better than the ripe plantain. The standard test dose of 2 I.U. per day of vitamin A induced an average weight gain of $28 \mathrm{gm}$. in 4 weeks. Two-tenths of a gram of green plantain and the same quantity of ripe plantain, administered as a supplement daily to depleted rats induced weight gains of 20 and $11 \mathrm{gm}$., respectively, in a 4-week period (see table 2).

Although the difference of a 9-gm. gain in weight in favor of the green plantain was not statistically significant, the fact that four animals died 
in the yellow-plantain group, and not a single animal died in the group receiving green plantain, is a further indication of the greater protective activity of the green over the yellow plantain. The samples of plantaind use in the rat assay were not the same ones used for chemical analyses.

\section{SUMMARY}

1. The carotene content of green and yellow plantains, as determined by the chromatographic assay procedure, averaged $10.43 \pm 3.66$ and 6.68 $\pm 2.97 \mu \mathrm{g}$. of carotene per gram of the raw edible portion, respectively.

2. Rat assay indicated that the green plantain protected more the vitamin A-depleted rats than the yellow plantain.

\section{RESUMEN}

1. El contenido de caroteno de los plátanos verdes y amarillos, según lo determinó el procedimiento que emplea el ensayo cromatográfico, fué $10.43 \pm 3.66$ y $6.68 \pm 2.97 \mu \mathrm{g}$. de caroteno, respectivamente, por gramo de la porción comestible sin cocinar.

2. El ensayo con ratones de laboratorio indicó que el plátano verde podía proteger mejor a los ratones faltos de vitamina $\mathrm{A}$ que el plátano amarillo.

\section{LITERATURE CITED}

1. Roberts, L. J., and Steffani, R. S., Patterns of living in Puerto Rican families University of Puerto Rico, Río Piedras, P. R., 1949.

2. Gómez, A., and Mattill, H. A., Ascorbic acid and carotene content of planta in, Food Res. 14 177-81, 1949.

3. Quinn, E. J., and Cook, D. H., The vitamin A content of white yautia, yellow yautia and plantain with further evidence of a possible relationship between the color of a natural food and its richness in vitamin A, Am. J. Trop. Med. 8 503-6, 1928.

4. Axtmayer, J. H., and Cook, D. H., Estudios sobre el valor nutritivo de las substancias alimenticias en la dieta ordinaria de Puerto Rico, V: El contenido de vitamina A de los siguientes productos vegetales: Apio, berenjena, calabaza, chayote, gandul, garbanzo, habichuela tierna, mamey, pimiento morrón, plátano verde hervido, quimbombó y yuca, $P . R$. J. Pub. Health and Trop. Med. 8 407-12, 1933.

5. Munsell, H. E., Williams, I. O., Guild, L. P., Troescher, C. B., Nightingale, G., and Harris, R. S., Composition of food plants of Central America, I: Honduras, Food Res. 14 144-64, 1949.

6. - Composition of food plants of Central America, III: Guatemala. Food Res. $1534-52,1950$.

7. Munsell, H. E., Williams, L. O., Guild, L. P., Troescher, C. B., Nightingale, G., Kelly, L. T., and Harris, R. S., Composition of food plants of Central America, IV: El Salvador Food Res. 15 263-96, 1950.

8. Munsell, H. E., Williams, I. O., Guild, L. P., Troescher, C. B., Harris, R. S., 
Composition of food plants of Central America, V: Nicaragua. Food Res. 15 355-65, 1950.

9. Munsell, H. E., Williams, L. O., Guild, L. P., Kelley, L. T., McNally, A. M., and Harris, R. S., Composition of food plants of Central America, VI: Costa Rica. Food Res. 15 379-404, 1950.

10. Munsell, H. E., Williams, L. O., Guild, L. P., Kelley, L. T., and Harris, R. S., Composition of food plants of Central America, VII: Honduras. Food Res. 15 421-38, 1950.

11. Cravioto, R. O., Massieu, G., Guzmán, J., and Calvo de la Torre, J., Composición de alimentos mexicanos, Ciencia 11 129-55, 1951.

12. Navia, M. N., López, H., Cimadevilla, M., Valiente, A., Clement, I. D., and Harris, R. S., Nutrient composition of Cuban foods, I: Foods of vegetable origin, Food Res. 20 97-113, 1955.

13. The Association of Vitamin Chemists, Inc., Methods of Vitamin Assay, Second Ed., 1951, pg. 52, Interscience Publishers, Inc., New York, N. Y.

14. U. S. Pharmacopoeia XIV Ed., pg. 787, Mack Publishing Co., Easton, Pa., 1950. 